\title{
Hematoxylin - Eosin-Methylene Blue Staining in a Dog Hepatic Amyloidosis Case
}

\author{
ADRIAN STANCU ${ }^{1}$, LILIANA CARPINISAN ${ }^{1 *}$, ALINA GHISE ${ }^{1}$, MARIUS PENTEA ${ }^{1}$, DELIA MIRA BERCEANU VADUVA ${ }^{2}$ \\ DANA EMILIA VELIMIROVICI², ROMEO CRISTINA ${ }^{2}$ \\ ${ }^{1}$ Faculty of Veterinary Medicine Timisoara, 119 Calea Aradului, 300645, Timisoara, Romania \\ ${ }^{2}$ Victor Babes University of Medicine and Pharmacy Timisoara, 2 Eftimie Murgu Sq., 300041, Timisoara, Romania
}

\begin{abstract}
A post-mortem examination of an 1,5 years old Shar-Peis, dog was performed in order to find out the death cause. The macroscopically examination revealed a large amount of blood in the abdominal (hemoperitoneum) The liver was sampled for histopathological examination. Hematoxylin-eosin-methylene blue staining wasperformed in order to prepare the samples for microscopical examination. Based on the specific histopathological changes and taking into account all the pathological data, the diagnosis was liver amiloidosis.
\end{abstract}

Key words: amiloidosis, Shar- Peis dog, hematoxylin-eosin-methylene blue staining.

When a dog's body produces new proteins, peptide chains are designed to fold into a certain shape. Insoluble proteins resistant to digestion result from incorrect folding, and when they are deposited in tissues, they displace normal cells in a condition called amyloidosis. Amylodiosis can occur throughout the body. Hepatic amylodiosis occurs when amyloids, or insoluble proteins, form deposits within the liver. Hepatic amyloidosis often occurs in conjunction with amyloidosis, or protein deposits, in other areas of a dog's body, such as the kidney, spleen, adrenal glands, pancreas, and gastrointestinal tract. There is a high risk of liver failure or failure of other affected organs, and amyloisis can be fatal. Amyloidosis can develop as the result of chronic inflammatory diseases, chronic bacterial infections and malignant tumors, or as a hereditary condition. Hereditary amyloisis occurs more commonly in Chinese Shar-Peis, Akitas, and Collies. Dogs with hepatic amylodiosis typically display symptoms of liver failure first; however, some may exhibit signs of kidney distress earlier $[3,7,10-14,17,19]$.

\section{Causes of Amyloidosis in Dogs Hereditary}

Inherited hepatic amyloidosis occurs as an affect of conditions that cause protein mutations. In Chinese SharPeis, it occurs as a result of cyclic fever specific to the breed that are known as Shar-Pei Fever Syndrome. Akitas are predisposed to develop amyloidosis as a result of cyclic fever and multiple joint inflammations. Collies who have Cyclic Neutropenia or Gray Collie Syndrome, which is a stem cell disorder, are also predisposed to developing amyloidosis.

\section{Acquired}

Acquired hepatic amyloidosis develops as a result of plasma cell tumors, or myelomas, causing overproduction of a certain protein, and severe inflammation as a result of chronic inflammatory diseases, chronic bacterial infections and malignant tumors.

\section{Senile}

Mild and asymptomatic amyloid formations occur to some extent in all elderly dogs as a simple result of age. These types of protein deposits are not likely to affect your dog's health, and, therefore, unlikely to be diagnosed. Amyloidosis is any disease entity characterized by the formation and deposition of amyloid. There have been more than 15 proteins. Regardless of which parent protein causes amyloid, microscopically, it all looks the same. Histologically it has a pale bluish-red (amphophilic) homogenous and amorphous appearance $[1,2,10,11$, 20].

Of the numerous proteins that can form amyloid, there are only 3 which are common and important in domestic animals. Amyloid associated (AA amyloid) is formed from a common acute phase protein called serum amyloid (SAA), amyloid light chain (AL amyloid) is formed from the light chains of immunoglobulins, and islet amyloid (IA amyloid) forms from a islet amyloid polypeptide (IAPP), a protein synthesized by islet b-cells. IA amyloidosis is most commonly seen in the pancreatic islets of old cats [15, 16].

Amyloidosis refers to a group of disorders that share a common feature: the pathologic abnormal deposition of a fibrous protein called amyloid into various tissues of the body.

In humans, a protein called amyloid precursor protein (APP) is an integral plasma membrane protein which is found in highest concentrations in neurons near synapses. Currently, no association of amyloid and Cognitive Dysfunction Syndrome, a syndrome in animals analogous to Alzheimer's, has been established.

However, the most common form of amyloidosis is idiopathic, when the condition cannot be linked to any of the above stated conditions.

Hepatic amyloidosis is the deposition of amyloid in the liver. The accumulation of amyloid often occurs secondary to an underlying inflammatory or lympho-proliferative disorder. For example, when lymphocytes, a type of white blood cell, are produced in excessive quantities, amyloidosis can be a reaction to this condition. Or, it can occur as a familial disorder. Most affected dogs are thought to have reactive or secondary amyloidosis affiliated with an underlying primary inflammatory disorder. Familial amyloidosis has been described in certain dog breeds. The most commonly affected breeds are Beagles, Shar-Peis, and Foxhounds [9].

\footnotetext{
*email: Icarpinisan@yahoo.co; danavelimirovici@yahoo.com, Phone: 0723211190
} 


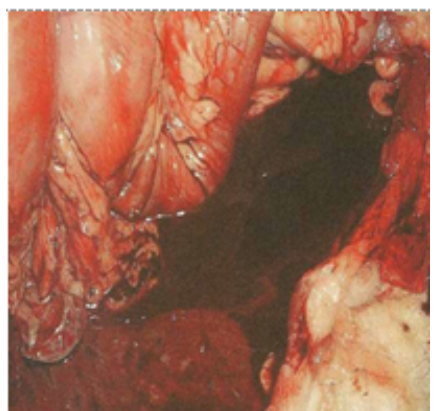

Fig.1. Dog. Blood in the abdominal cavity (hemoperitoneum)

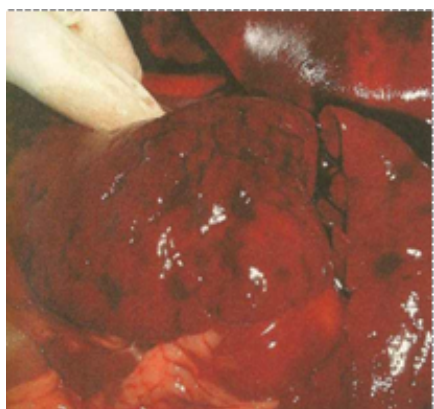

Fig.2.Dogliver.Grossly,hepatic amyloidosis. There are several cracks and fractures on the surface
In the liver, severe amyloidosis can eventually cause chronic liver failure by its slow atrophy and destruction of hepatocytes. More commonly, however, hepatic amyloidosis leads to fatal abdominal hemorrhage. In severe cases, the presence of the amyloid markedly weakens the structural integrity of the liver, making it very friable. Because of this friability, minor trauma to the liver can result in fracturing/cracking of the parenchyma, severe hemorrhage, and death from exsanguination.

Multiple organs are commonly involved. Clinical signs are usually associated with renal (kidney) involvement. Or it may be associated with high liver enzymes, severe enlargement of the liver, coagulation disorders, liver rupture leading to hemoabdomen (blood in the abdomen), and/or liver failure. Liver amyloid accumulation is often insidious $[6-8,13]$.

\section{Experimental part}

\section{Materials and methods}

It was performed an 8 years old German Shepherd dog post-mortem examination, following a sudden death. There were taken spleen samples for histopathological examination.

The samples preparation was carried out as follows: 24 $\mathrm{h}$ alcohol fixation at room temperature (prevent the tissue alteration due to the enzymes activity; preserve the tissue texture; improves the optical differentiation), alcohol dehydration (five steps: $70,80,90,100 \%$ and $100 \%$ alcohol, each step for two hours), clearing with benzene, paraffin wax at $56^{\circ} \mathrm{C}$, embedding tissues into paraffin blocks, trimming of paraffin blocks ( 6 im), sections mounting on the glass slides (using Meyer albumin), hematoxylin eosin- methylene blue staining. Staining was performed as follows: deparaffination of tissue sections in benzene, rehydration using decreasing concentrations of alcohol, rinsing in distilled water, hematoxylin staining, alcohol, eosin staining and methylene blue staining, water removal using increasing concentrations of alcohol, cover slide mounting . Hematoxylin will stain the nuclei in blue and the mucins in light blue. Eosin will stain the cytoplasm in pink, collagenin pale pink, red blood cells in bright red, and colloid in red.Methylene blue improves the blue colour of the nuclei, making them more observable. The microscopical examination is useful as differentiating diagnosis method only if chemical preparation of samples is applied $[4,5,18]$.

\section{Results and discussions}

The gross examination of the Sharpeis dog cadaver revealed no pathological signs. Following necropsy, a large amount of blood was observed in the abdominal cavity (hemoperitoneum) (fig. 1).

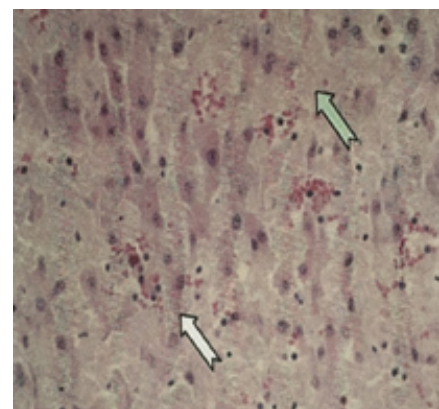

Fig 3 Microscopic hepatic amyloidosis. Notice how the hepatic cords (white arrow) are thin and atrophic, being separated an compressed by the pale amorphous amyloid (green arrow) in the sinusoids

The liver gross examination revealed a swollen, puffy appearance, and there are several cracks and fractures on the surface which have resulted in fatal hemorrhage [9]. (fig. 2).

Hepatic amyloidosis leads to fatal abdominal hemorrhage. In this several cases, the presence of the amyloid markedly weakens the structural integrity of the liver, making it very friable. Because of this friability, minor trauma to the liver resulted in fracturing/cracking of the parenchyma, severe hemorrhage, and death from exsanguination [21].

The complete examination of the cadaver does notshow other pathological lesions.

Microscopic hepatic amyloidosis. The hepatic cords (white arrow) are thin and atrophic, being separated and compressed by the pale amorphous amyloid in the sinusoids ( fig. 3). This separation and destruction of the hepatic cords weakens the liver's structural integrity, predisposing it to fracturing and hemorrhage.

\section{Conclusions}

The Shar-Peis dog post mortem gross examination revealed hemoperitoneum, and several cracks and fractures on the liver surface, based on the specific literature data, lead to the presumption of liver amiloidosis.

The confirmation of diagnosis was made taking into account the histopathological examination of the liver samples, following hematoxylin-eosin-methylene blue taining. The presence of the specific histopathological aspects confirmed the liver amiloidosis diagnosis.

The rare founded pathological aspects (once in 5 years), show that liver amiloidosis has quite low frequency in dogs.

Acknowledgements: This research work was carried out with the support of the project Dezvoltarea infrastructurii de cercetare, educape oi servicii în domeniile medicinei veterinare oi tehnologiilor inovative pentru RO 05, cod SMIS-CSNR 2669.

\section{References}

1.STANCU, A., General veterinary pathological anatomy 2014, Editura Agroprint, 978-ISBN - 606-8037-50-3.

2.STANCU, A., Practicum of veterinary pathological anatomy 2014, Editura Agroprint, ISBN - 978-606-8037-48-6.

3.STANCU,A., Special veterinary pathological anatomy 2014, Editura Agroprint, 978- ISBN - 606-8037-49-3.

4.STANCU, A., PENTEA, M., AHMADI, M., CARPINISAN, L., GHISE, A., POPOVICI, R.A., CRISTINA, R., Hematoxylin-eosin-methylene Blue Staining in a Dog Thromboembolism Case, Rev. Chim.. (Bucharest), 66, no. 11, 2015. p. 1763

5.STANCU, A., CRISTINA, R., AHMADI, M., CARPINISAN, L., GHISE, A., PENTEA, M., BERCEANU VADUVA, D.M., Hematoxylin - eosin-methylene 
Blue Staining in a Dog Hemangiosarcoma Case, Mat. Plast., 52, no. 4, 2015, p. 514

6.COTOI, O.S., SUCIU, M., PACURAR, M., ORMENISAN, A., Rev. Chim. (Bucharest), 66, no. 2, 2015, p. 219

7.FARRELL LL, SCHOENEBECK J , WIENER P, CLEMENTS DN, SUMMERS KM -The challenges of pedigree dog health: approaches to combating inherited disease. Canine Genetics and Epidemiology 2015. 8.FLAT, B., MOORE, R. R., WOLF, C. M., YEOMANS, S. M., DONNEL, R. L., LANE, I. F. AND FRY, M. M.: Liver aspirate from a Shar Pei dog. Vet Clin PatholMar; 2007.No. 36(1):pp. 105-108

9.FLATLAND B et al Liver aspirate from a Shar Pei dog. Vet Clin Pathol 2007, No. 36(1):pp. 105-108.

10.J OHNSON KH, SLETTEN K, HAYDEN DW, O'BRIEN TD, ROSSOW KD AND WESTERMARK P AA amyloidosis in Chinese Shar-pei dogs: Immunohistochemical and amino acid sequence analyses. Amyloid 1995, Vol 2: pp. 92-99.

11.J OHNSON KH, WESTERMARK P, SLETTEN K AND O'BRIEN TD Amyloid proteins and amyloidosis in domestic animals. Amyloid 1996, Vol. 3: pp. 270-289.

12.MAY C, HAMMILL J AND BENNETT D Chinese Shar-pei fever syndrome: a preliminary report. The Veterinary Record 1992, No. 131: pp. 586-587.

13.PA'CA AURELIAN SORIN - Probleme de patologie renala la caine, 2014, Ed. Ion Ionescu de la Brad Iasi, ISBN 978-973-147-158-7.
14.PICKEN, M. M. The changing concepts of amyloid. Arch Pathol Lab Med. 2001: No. 125:pp. 38-41.

15.RIVAS AL, TINTLE L, KIMBALL ES, SCARLETT J AND QUIMBY FW A canine febrile disorder associated with elevated interleukin-6. Clinical Immunology And Immunopathology 1992, No. 64: pp. 36-45.

16.RIVAS AL, TINTLE L, MEYERS-WALLEN V, SCARLETT J M, VAN TASSELL CP AND QUIMBY FW Inheritance of renal amyloidosis in Chinese Shar-pei dogs. The J ournal Of Heredity 1993, No. 84: pp. 438442.

17.SEGEV ET AL -Renal amyloidosis in dogs: a retrospective study of 91 cases with comparison of the disease between Shar-Pei and nonShar-Pei dogs. J Vet Intern Med 2012, No. 26(2):pp. 259-268.

18.SINCAI M., Tehnici de citohistologie normalã $p$ patologicã. Ghid practic, Ed. Mirton, Timisoara, 2000. pp.6.

19.TAKEUCHI, M. AND MATSUE, K. -Primary amyloidosis associated with IgD-2007.

20.URIELI-SHOVAL S, LINKE RP AND MATZNER Y Expression and function of serum amyloid $A$, a major acute-phase protein, in normal and disease, 2000.

21.ZINI, E., HAUSER, B., MELI, M. L. AND GLAUS, T. M. Transient laboratory changes in a cat with repeated hepatic haemorrhage due to amyloidosis. Vet Rec. Jan 2008: Vol 5; No. 162(1):pp. 24-26.

Manuscript received: 30.01 .2017 